\title{
A clinical case of the retroperitoneal fibrosis (Ormond's disease) in rheumatology practice
}

\author{
For citation: Bol', sustavy, pozvonočnik. 2021;11(1):42-49. doi: 10.22141/2224-1507.11.1.2021.226909
}

\begin{abstract}
Retroperitoneal fibrosis (RPF) is a rare disease characterized by the proliferation of inflammatory and fibrous tissue in the retroperitoneum. These masses are commonly localized around the infrarenal part of the abdominal aorta and iliac arteries, often covering the ureters or other organs of the abdominal cavity; idiopathic diseases accounting for $70 \%$ of cases. RPF may be associated with immunoglobulin G4 (IgG4), which accounts for two-thirds of idiopathic RPF cases. Secondary RPF may develop due to infections, malignant neoplasms, medication, retroperitoneal bleeding, or various other diseases. A clinical case of idiopathic RPF, probably associated with IgG4, was described in a patient who had undergone a symptomatic surgical treatment in an urological clinic and continued being treated by a rheumatologist, given pathogenetic therapy (methylprednisolone and mycophenolate mofetil) with a significant improvement. For rheumatologists, this pathology is of an undoubted clinical interest, since these changes are based on processes similar to those occurring in systemic diseases of the connective tissue, and the RPF is extremely rare, ranging from 0.1 to 1.3 cases per 100,000 patients per year. However, more often than not, such patients are referred to the doctors of ancillary specialties (urologists, nephrologists, surgeons, vascular surgeons). All of the abovementioned facts emphasize the importance of analyzing such a clinical case.
\end{abstract}

Keywords: retroperitoneal fibrosis; IgG4-associated disease; clinical case; diagnosis; treatment

\section{Introduction}

Retroperitoneal fibrosis (RPF) is a rare disease characterized by an inflammatory and fibrous tissue proliferation in the retroperitoneal area. These proliferations are localized around the infrarenal section of abdominal aorta and iliac arteries; they are often coating the ureters and other organs of abdominal cavity [1]. In 1984, the disease was first described by J. K. Ormond and named in his honour [2]. However, there are other names associated with this pathology: fibrous periurethritis, plastic periurethritis and fibrous retroperitonitis. The scientists distinguish between a primary (idiopathic) and secondary RPF; idiopathic conditions accounting for $70 \%$ cases. The RPF may be associated with G4 immunoglobulin (IgG4), which results in 2/3 of idiopathic RPF cases [3]. The secondary RPF may develop due to infections, malignant neoplasms, and a history of certain medications, retroperitoneal bleeding and other conditions. The RPF is a rather rare disease. According to various studies, the frequency of idiopathic (primary) conditions varies from
0.1 to 1.3 cases per 100,000 subjects annually [4]. The subjects aged 40-60 years, namely men, predominate in a ratio of 2:1 to 3:1. Some authors [5] refer to an increased RPF risk associated with tobacco smoke or asbestos.

The secondary RPF's frequency is not yet clear. Over $70 \%$ cases are afflicted by the idiopathic RPF, which is an immune-mediated condition; it may develop both independently and accompany the IgG4-associated diseases. Among the pathogenetic factors, there are genetic associations with HLA-DRB1 antigen system under the environmental factors such as asbestos and smoking. These agents affect the CD4+ T-cells of aorta and retroperitoneal area, promoting their proliferation and interleukin (IL) 6 secretion, and further on, activating the B-cells and fibroblasts [6]. The CD4+ T-cells are also secreting IL-4, IL-10, IL-13 and transforming growth factor beta (TGF- $\beta$ ), stimulating the B-cell proliferation and maturity into the plasmatic cells, and as a result they may provoke the predominance of $\mathrm{IgG} 4$-producing plasmatic cells [7].

C) 2021. The Authors. This is an open access article under the terms of the Creative Commons Attribution 4.0 International License, CC BY, which allows others to freely distribute the published article, with the obligatory reference to the authors of original works and original publication in this journal.

Для кореспонденції: Єгудіна Єлизавета Давидівна, доктор медичних наук, професор, керівник освітнього центру, клініка сучасної ревматології, м. Київ, Дніпровська набережна, 25, м. Київ, 49000, Україна; e-mail: elizavetaegudina@gmail.com; контактний тел. +38(099)0595475.

For correspondence:Ye.D. Yehudina, MD, PhD, professor, Head of the Educational Center, Clinic of Modern Rheumatology, Dniprovska embankment, 25, Kyiv, Ukraine; e-mail: elizavetaegudina@gmail.com; phone +38(099) 0595475.

Full list of authors information is available at the end of the article. 
This pathology may be of clinical interest for the rheumatologists, as these changes are based on the processes, similar to those attending the systemic connective tissue disorders. In this regard, we find it instructive to present our description of RPF case, undergoing symptomatic surgery at the urology clinic, and referred to the rheumatologist for the pathogenetic therapy.

\section{Clinical case}

In October 2020, the 62-year-old patient B. presented himself to a rheumatologist, complaining of lumbar pain generated by the physical activity, general weakness, headache, nausea and vomiting after food and water consumption, xerostomia, weight loss of up to $6 \mathrm{~kg}$ during the previous month due to a lack of appetite, body temperature surges up to $37.2-37.5^{\circ} \mathrm{C}$, headache and arterial blood pressure reaching 180/120 $\mathrm{mm} \mathrm{Hg}$.

Since August 2020, the patient considers himself sick. He gradually started to suffer from strangury, lower abdominal and lumbosacral pains, nausea and vomiting. He was examined by the family physician; due to a suspected renal pathology, he was referred to an urologist for consultation. The patient was admitted to the urology department from 4.09.2020 to 28.09.2020, and diagnosed with: a bilateral ureterohydronephrosis, chronic kidney disease (CKD) of stages III-IV, nephrogenic hypertension, massive neoplasm in the retroperitoneal area. The percutaneous nephrostomy was performed by direct puncture on the left side 17.09.2020, and on the right side 29.09.2020 (Fig. 1, patient's photo).

Details of anamnesis vitae: tuberculosis, diabetes mellitus, patient denies viral hepatitis type A (Botkin's disease), his father had a stroke. In 2000, the patient had appendectomy, peritonitis; in 2007, phimosis-related circumcision; in 2010, he had undergone repair of inguinal hernia on both sides.

The examination revealed an aggravated condition, forced posturing; the patient uses wheelchair due to the general weakness and dizziness. The peripheral lymph nodes are barely palpated. No peripheral edema present. The cutaneous covering is pure, coloring normal. There is a clear pulmonary sound over the whole lung perimeter; vesicular breathing at auscultation, no rales. The borders of relative cardiac dullness: the right border - the IV intercostal space on the right sternal edge; the upper border - the III intercostal space at the left parasternal line; the left border - the V intercostal space at the left medioclavicular line. At auscultation, the heart tones are muffled, the cardiac activity rhythmic, the 2 tone on the aorta is unclear, arterial blood pressure is $100 / 60 \mathrm{~mm} \mathrm{Hg}$. The heart rate is 88 beats per minute (bpm), satisfactory quality, rhythmic. The tongue is dry, furred with whiteyellow deposit.

At palpation, the stomach is soft, not painful. The liver is palpated near the edge of costal arch, the spleen is not palpated. The costovertebral angle (CVA) tenderness is negative on both sides. There are nephrostomes inserted around both kidneys, in both urinals the liquid is lightyellow (300 $\mathrm{ml}$ in the right one, $1500 \mathrm{ml}$ in the left one).
The stool is of normal color and consistency, no pathological substances added. The laboratory findings are presented in Tables 1 and 2.

Besides the above-mentioned tests, the patient had undergone the following lab examinations: 6.10.2020 C-reactive protein (CRP) - $60 \mathrm{mg} / \mathrm{L}, \mathrm{RF}-10 \mathrm{IU} / \mathrm{mL}$, antinuclear antibody (ANA) test $-0.82 \mathrm{IU} / \mathrm{mL}$ (negative), carcinoembryonic antigen (CEA) test $-1.64 \mathrm{ng} /$ $\mathrm{mL}$ (negative), iron $-16.4 \mu \mathrm{mol} / \mathrm{L}$, total cholesterol $4.73 \mathrm{mmol} / \mathrm{L}$, triglycerides - $1.55 \mathrm{mmol} / \mathrm{L}$, high-density lipoproteins (HDL) - $1.46 \mathrm{mmol} / \mathrm{L}$, low-density lipoproteins (LDL) - $2.57 \mathrm{mmol} / \mathrm{L}$, very-low-density lipoproteins (VLDL) $-0.70 \mathrm{mmol} / \mathrm{L}$, atherogenic index - 2.20; coagulogram: International Normalized Ratio (INR) -0.95 , Quick value $-107.4 \%$, prothrombin time $(\mathrm{PT})-12.7$, Fibrinogen $(\mathrm{FF})-5.6 \mathrm{~g} / \mathrm{L}$. Due to the epidemiological situation, the patient was examined for COVID infection (IgM SARS-CoV2) - 0.19 U (negative). 13.10.20 polymerase chain reaction (PCR) to SARS-CoV2 - 0.19 U (negative). The patient has an increased $\mathrm{IgG}$ level $-300 \mathrm{mg} / \mathrm{dL}$ (normal level up to $100 \mathrm{mg} / \mathrm{dL}$ ).

The following instrumental studies were performed: chest X-ray: no infiltrating and inflammatory changes; thoracic X-ray: spondylosis deformans $\left(\mathrm{Th}_{5}-\mathrm{Th}_{11}\right)$, osteochondrosis $\left(\mathrm{Th}_{7}-\mathrm{Th}_{11}\right)$, lumbar spine: diffuse spondylosis deformans, spondyloarthritis, osteochondrosis $\left(\mathrm{L}_{1}-\mathrm{L}_{3}\right)$, signs of bilateral sacroiliitis. Magnetic resonance imaging (MRI) of sacroiliac joint (SIJ): no evidence of sacroili-

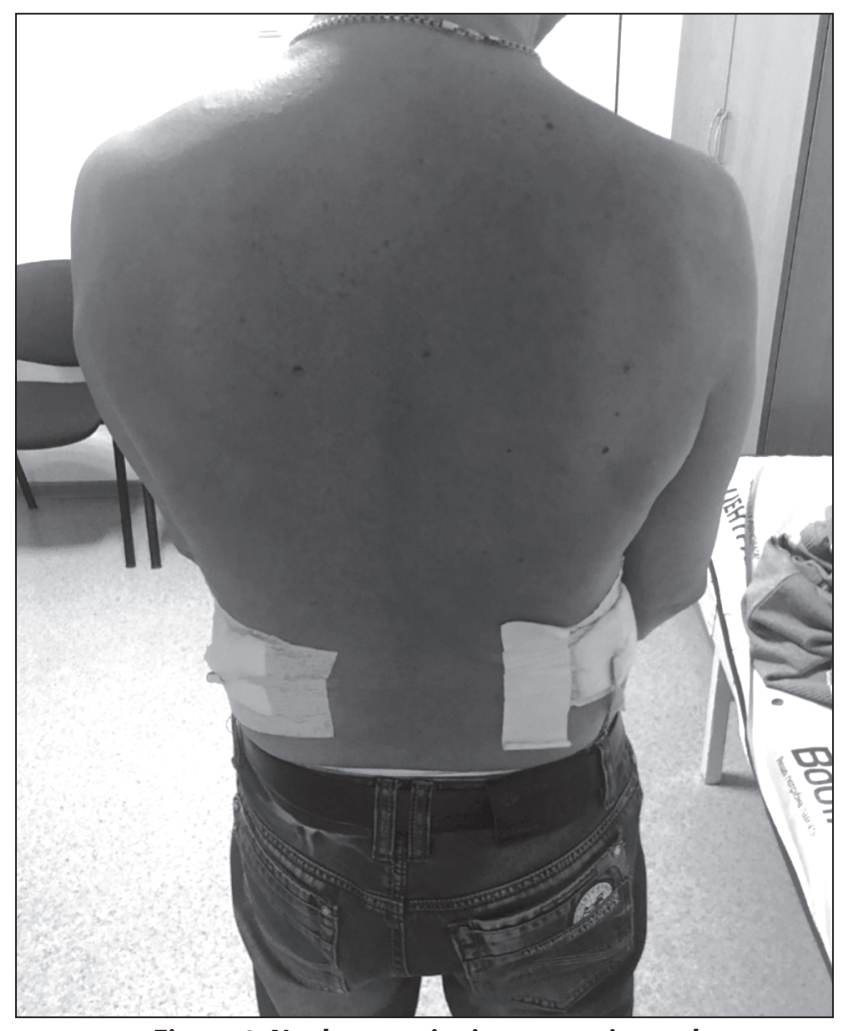

Figure 1. Nephrostomies in retroperitoneal fibrosis patient

Note. The written informed consent for participation and publication of data were given by the patient. 


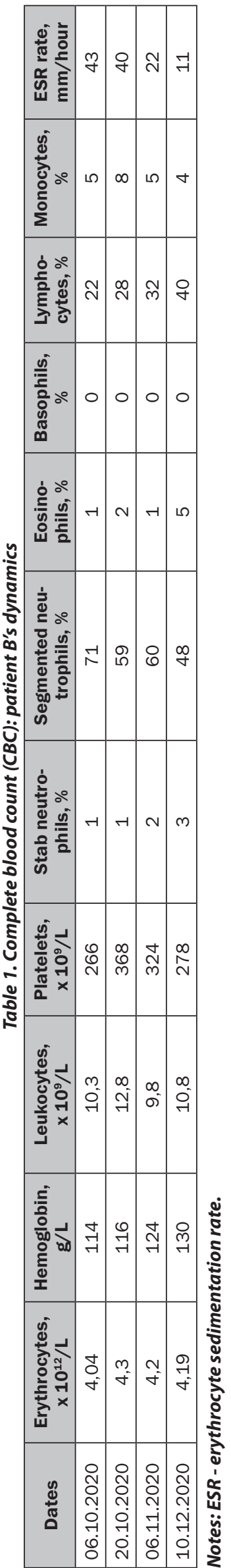

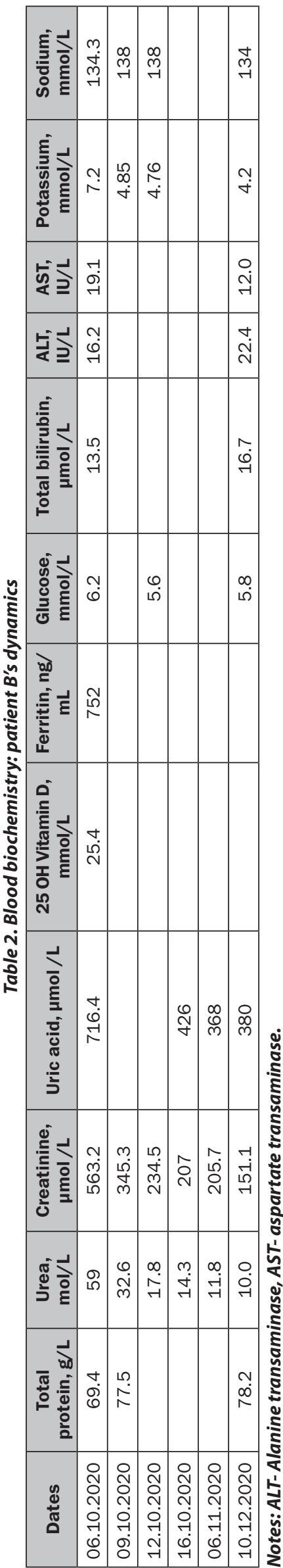

itis. Esophagogastroduodenoscopy (EGD) - erosive gastropathy, erosive bulbitis, duodenal bulb ulcer with signs of fibrin. Electrocardiography (ECG): sinus tachycardia, sings of hypertrophic left ventricular myocarditis.

Conclusion of multislice (64 slices) spiral computed tomography (MSCT) of thoracic, abdominal, retroperitoneal, pelvic area with contrast (25.09.2020): massive tumor in the retroperitoneal area, mediastinum at the examined level, invasion of ureter - signs of retroperitoneal fibrosis. The postcava at the level of infrahepatic compartment is located deep within the infiltrative component, the lumen is irregular. The right-side hydronephrosis, left-side pyeloectasia, post-nephrotomy condition. Retroperitoneal lymphadenopathy. Hepatomegaly. Left-side minor hydrothorax. Magnetic resonance imaging of thoracic, abdominal, retroperitoneal and pelvic organs with contrast (in dynamics, 02.10.2020): signs of diffuse thickening of aortic wall along its length, present infiltrative paraaortal component with ureteral obstruction, presumably as a result of chronic periaortitis (Fig. 2).

While performing the ultrasound dopplerography of leg vessels along the abdominal segment of aorta, predominantly along the anterior wall, the healthcare providers found a 2 -cm-thick neoplasm, moderately vascularized, $6 \mathrm{~cm}$ above the bifurcation, which envelops the aorta circularly. The heart echocardiography: signs of atherosclerotic aortocardiosclerosis and hypertrophic left ventricular myocarditis, expansion of thoracic aortal segment, thickening of aortal and mitral valve cusp; mitral regurgitation of stage $0-1$, tricuspidal regurgitation of stage $0-1$ (mean pulmonary artery pressure of $17 \mathrm{~mm} \mathrm{Hg}$, no pulmonary hypertension). The ultrasound examination of abdominal organs and kidneys: signs of diffuse pathology of liver parenchyma, signs of chronic cholecystitis, pancreatitis. Insignificant bilateral pyeloectasia. Signs of diffuse pathology of kidney parenchyma with bilateral pyelonephritis signs. Along the anterior wall of abdominal aortic segment, from xiphoid process to navel, the healthcare providers observe the echo-irregular tissue neoplasm, which is located circularly, irregularly thickened along its span from 17 to $23 \mathrm{~mm}$, with blood flow visible at the Doppler color flow mapping (Fig. 3). In the area of right kidney's lower pole's projection, a similar neoplasm of 43 per $35 \mathrm{~mm}$ is visible at the paranephral level. These tissue neoplasms correspond to the retroperitoneal fibrosis. At the antegrade pyelography, the right ureter is patent; there is a blockage of left kidney at the level of the upper third of left ureter (Fig.4).

The patient was consulted by a surgeon and oncourologist at the Kharkiv Oncology Center: biopsy is impossible due to a threat to the patient's life.

Taking into account the MSCT and ultrasound findings, revealing the renal function disorder, ureteric obstruction, periaortitis, and ruling out the secondary causes of tumor-like neoplasm, as well as the latter's characteristic location, the patient was diagnosed with the following: Primary diagnosis: Idiopathic retroperitoneal fibrosis 
(Ormond's disease) - periureteric fibrosis with ureteric obstruction. Bilateral ureterohydronephrosis. Percutaneous nephrostomy and direct puncture on the left 17.09.2020 and on the right 29.09.2020. Complications of the primary diagnosis: CKD of stage IV (EPI glomerular filtration rate $\left.(\mathrm{GFR})-31 \mathrm{~mL} / \mathrm{min} / 1.73 \mathrm{~m}^{2}\right)$, vascular lesions: periaortitis with abdominal aorta involvement, common iliac arteries, upper and lower mesenteric, renal arteries, engaging postcava at the level of infrahepatic compartment (CT data of 25.09.20). Secondary neph- rogenic arterial hypertension of stage 2, degree 2, high risk, heart failure (HF) of stage 1. Lymphadenopathy: retroperitoneal lymphadenopathy. Attending diagnosis: Vitamin D deficiency. Ulcer disease, active phase, active duodenal bulb ulcer. Chronic atrophic hyperplastic erosive gastroduodenitis with acid-producing gastric function. Diaphragm ulcer. Chronic noncalculous cholesystitis, beyond complications. Chronic pancreatitis, beyond complications. A possible diagnosis relevant for this patient - probable IgG4-associated condition, according

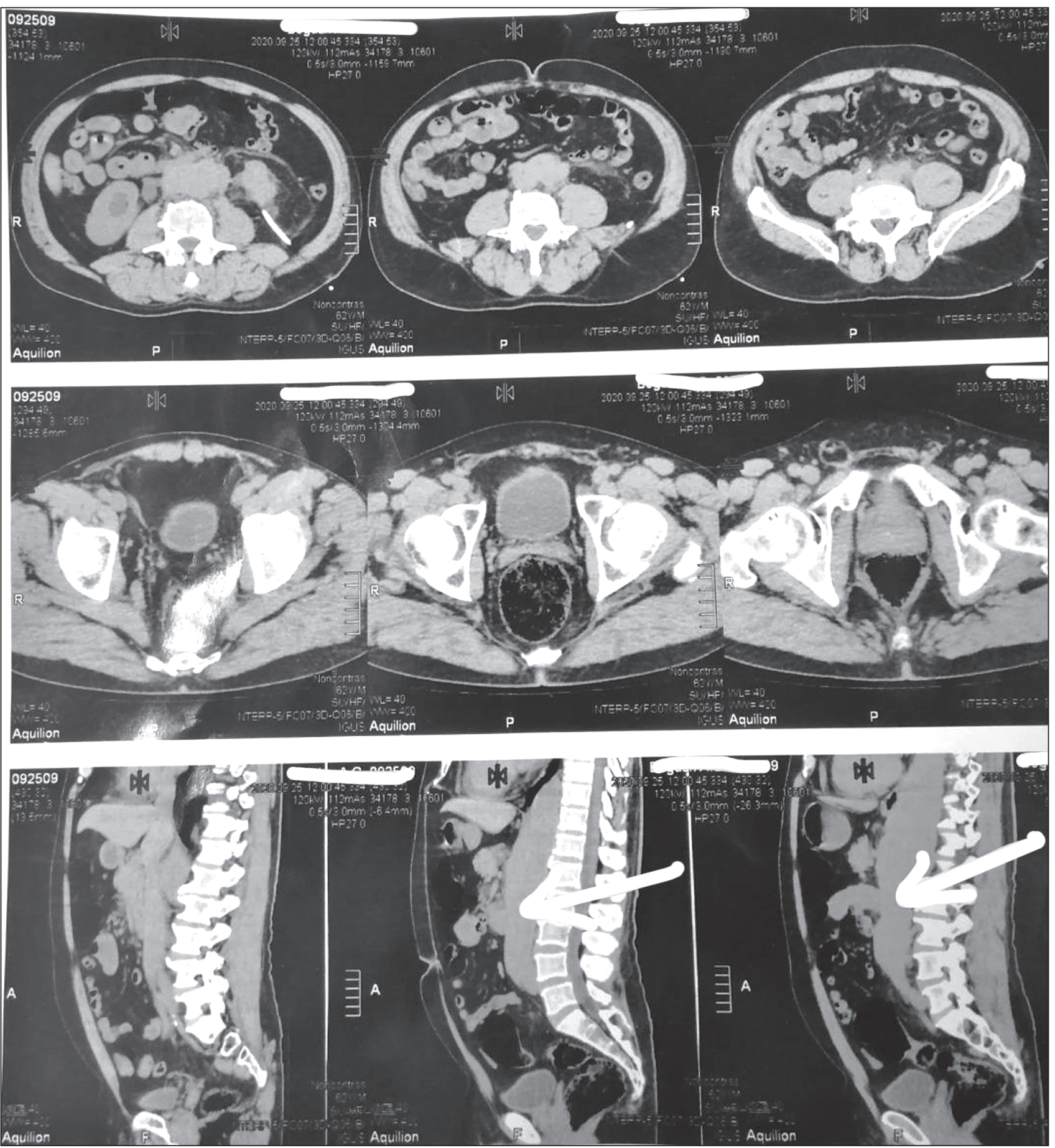

Figure 2. Magnetic resonance imaging of thoracic, abdominal, retroperitoneal

and pelvic organs with contrast (02.10.2020): signs of diffuse thickening of aortic wall along its length, present infiltrative paraaortal component. 
to H. Umehara et al.'s comprehensive criteria [8], as there is a retroperitoneal fibrosis and IgG4's increase up to $135 \mathrm{mg} / \mathrm{dL}$. However, the modern ACR/EULAR diagnostic criteria imply 20 points and over, while the present case has only 14 points [9]. This patient's biopsy was not performed due to some technical difficulties and threats to his life, reflected in the oncologist's and surgeon's conclusions. We have performed a thorough oncological search, and malignant neoplasm was ruled out.

The patient was treated at the rheumatology department (Dexamethasone IV for 5 days in a row, $48 \mathrm{mg}$ Methylprednisolone tablet a day, glucose, insulin, $1 \mathrm{~mL}$ Metoclopramide intramuscularly for 7 days, $5 \mathrm{mg}$ Concor a day, $20 \mathrm{mg}$ Omeprazole twice a day), as well as receiving medication for ulcer disease (antibacterial therapy, Bismuth medications) with a minor positive effect of reduced shortness of breath (SOB), nausea, reduced urea and creatinine indices, duodenal ulcer scarring; however, the pathogenetic therapy implies immunosuppressive treatment. According to the reference data, glucocorticoids calculated as $1 \mathrm{mg} / \mathrm{kg}$ by prednison are considered the key method of idiopathic retroperitoneal fibrosis (RPF) [10]. On discharge, the patient was prescribed a daily $48 \mathrm{mg}$ Methylprednisolone dose and $4000 \mathrm{IU}$ Vitamin $\mathrm{D}$ dose, and as a result a certain positive dynamics was achieved, both in terms of general health and urea and creatinine level reduction. However, taking into account the nitrogen metabolism and general lab activity, no positive dynamics registered by MSCT (the size of infiltrative paraaortal neoplasm remains intact, aorta is thickened diffusely) in November 2020, the patient was prescribed an additional daily $2 \mathrm{~g}$ dose of Mycophenolate mofetil (MMF). The MMF prescription was based on the recent randomized control trial, where 69 patients with IgG4-associated condition and RPFwere receiving either a glucocorticoid (GC) monotherapy (initial dose of 0.6$0.8 \mathrm{mg} / \mathrm{kg}$ ) or a combined GC and MMF therapy in a low dose (1.0-1.5 g/day) [11]. After 1 month, the effectiveness of two regimens of immunosuppressive therapy was comparable; however, after 1 year, the patients receiving the combined therapy had a significant increase of remission frequency $(76.5 \%$ vs. $51.4 \%)$ and reduction of cumulative relapse frequency $(20.6 \%$ vs. $40.0 \%)$. There is a high frequency of RPF relapses, remote adverse effects and a lack of disease control associated with GC monotherapy; one also emphasizes the necessity of combined GC and immunosuppressive medication use [12].

At the follow-up visit of 10.12.2020, there was a registered general health improvement, the shortness of breath, nausea disappeared, the urea level reduced to $10.0 \mathrm{mmol} / \mathrm{L}$ and creatinine to $151 \mu \mathrm{mol} / \mathrm{L}$, hemoglobin level normalized, the inflammatory activity index (ESR) of $11 \mathrm{~mm} /$ hour, CRP of $6 \mathrm{mg} / \mathrm{l}$. The patient continues taking MMF in a dose of $2 \mathrm{~g}$ per day, the Methylprednisolone dose should be reduced by $2 \mathrm{mg}$ per week under the activity control, while the Vitamin D use should be continued. The patient is referred for a repeat urologist's consultation to determine the further treatment tactics. On 16.12.2020, the antegrade pyelography was performed: there is a positive dynamic - the right ureter is patent, though the left kidney blockage is preserved at the level of upper third of left ureter (Fig. 4). The principal condition's treatment is to be continued, with a control session after 3 months.

\section{Discussion}

According to the reference data [10], one should monitor the patient's response to medication during the first month after the initiation, in order to assess the improvement of clinical symptoms, cessation of pain and release of obstruction. In the future, the clinical assessment of symptoms and lab results, namely the ESR, CRP and creatinine, should be performed every 2-3 months. The MSCT is performed a month after the therapy initiation,

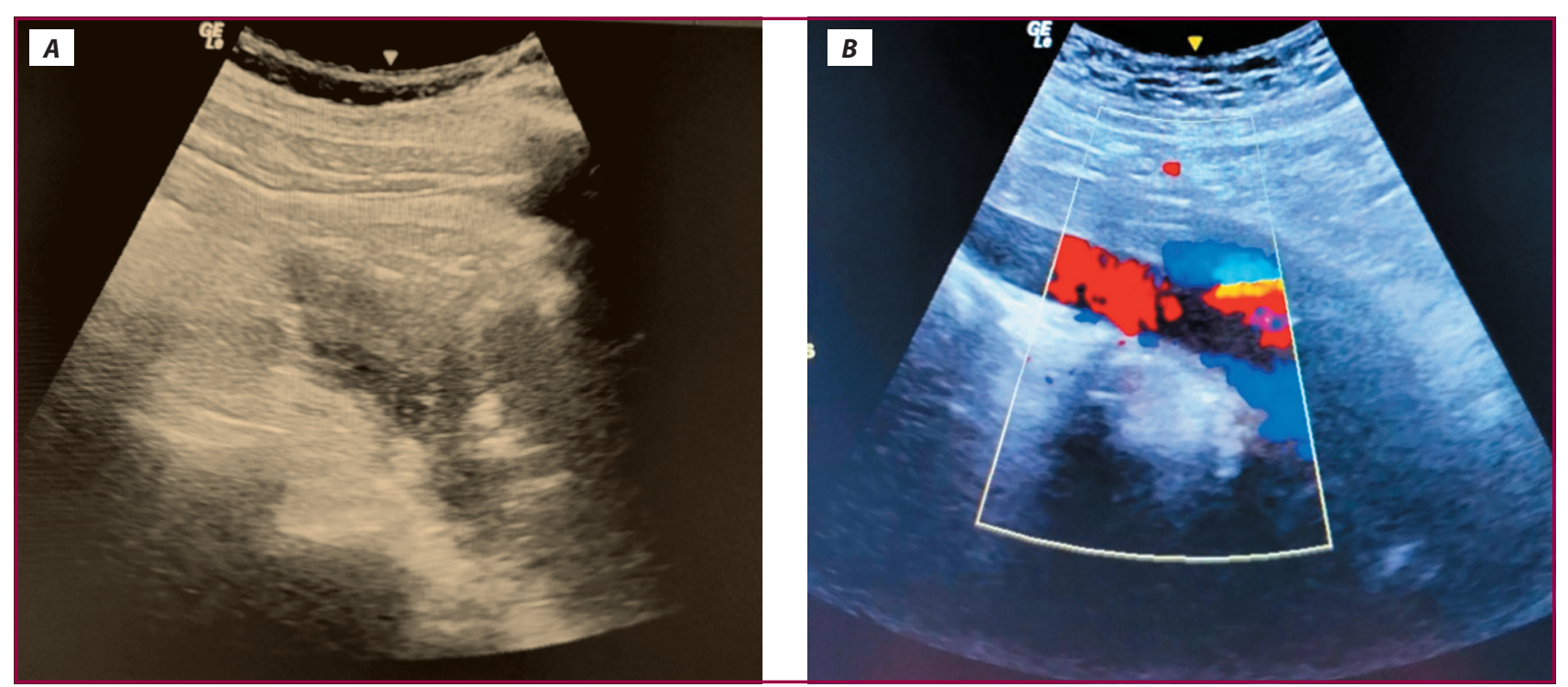

Figure 3. Ultrasound examination of abdominal organs

Notes: Echo-irregular tissue neoplasm of 17 to $23 \mathrm{~mm}$, located circularly along the anterior wall of abdominal aortic segment (A), with the Doppler color flow mapping (B). 
then about every 4-6 months, to watch over the size of fibrous masses. Further on, the retroperitoneal fibrosis patient should be examined every 6-12 months, the MSCT performed every 1-2 years. Some researchers describe the cases of relapse occurring 10 years after the therapy termination [13].

While analyzing this clinical case, one should emphasize the following points.

It is the first time we're facing such a rare pathology as retroperitoneal fibrosis. Its frequency varies from 0.1 to 1.3 cases per 100,000 subjects a year. That's why our clinical observation has a doubtless value due to an experience we've gained while diagnosing and curing the patient (who is still on our watch).

Urological surgery on its own has a purely symptomatic function; it does not modify the course or continuing progression of fibrous changes.

No doubt, the pathohistological examination would assist in differentiation of isolated RPF from the IgG4associated one. However, in the present circumstances biopsy is not always possible due to the technical issues. Besides, the patients with a typical fibrous mass localization and no clinical or lab manifestations of malignant process do not require an open biopsy or surgery unless the mass is not regressing with obstruction-releasing medication. There is no difference in treatment for the isolated or the IgG4-associated form. This is why we initiated the pathogenetic treatment without any pathohistological examination.

Prescribing cytostatic pathogenetic therapy (Methylprednisolone and MMF), we have managed to reduce the clinical manifestations considerably and to improve the patient's life quality.

To sum up, RPF is an extremely rare and difficult-tocure pathology; it is of great interest for both the rheumatologists and ancillary specialists (urologists, nephrologists, surgeons, vascular surgeons). This fact is attributed to the rarity, i.e. the patients addressing the surgeons, nephrologists, urologists for help are sent in for surgery. On the other hand, there are no clear-cut methods of diagnostic verification, the diagnostic criteria being complex

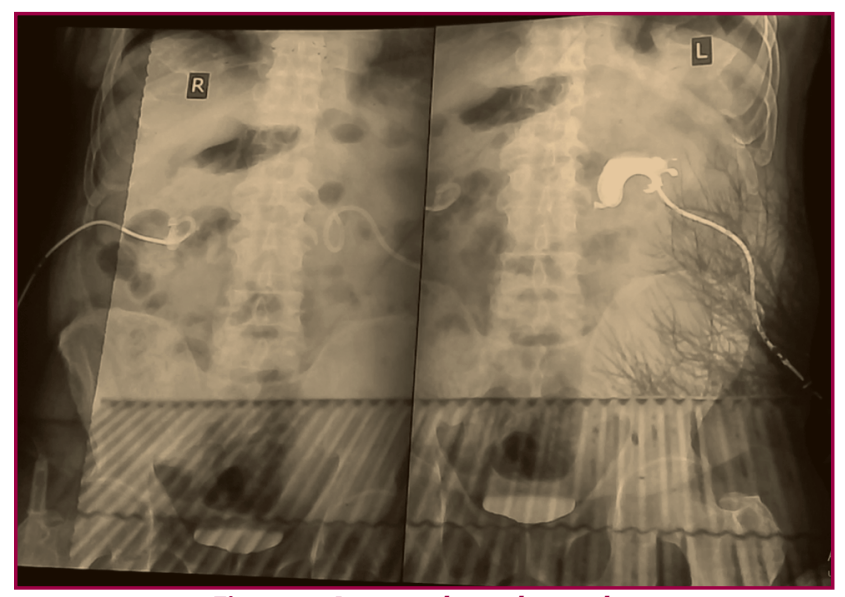

Figure 4. Antegrade pyelography.

The right ureter is patent, left kidney blockage at the level of upper third of left ureter and decision-making on the systemic glucocorticoid and cytostatic therapy (in case of massive fibrous proliferations compressing vessels and internal organs of various localizations) takes a long time, delaying the adequate treatment. The grave lesions of internal organs, as well as an inclination for relapse, compromise the life quality and require a regular monitoring. It is vital to discuss similar rare cases in order to raise awareness among the physicians and to provide a joint multidisciplinary treatment of such patients by rheumatologists, urologists, nephrologists, cardiologists and other specialists.

\section{Conclusions}

The Ormond's disease (retroperitoneal fibrosis) should be thoroughly studied, and the standards of treatment should be developed in order to secure the well-being of patents with this pathology.

The immunosuppressive therapy should be prescribed at the earliest possible time, in order to prevent the irreversible fibrosis.

With advanced stages, one should proceed to a complex treatment, involving both medication and surgery.

Conflicts of interests. Authors declare the absence of any conflicts of interests and their own financial interest that might be construed to influence the results or interpretation of their manuscript.

Funding: no.

Authors' individual contributions: Yehudina Ye.D., Trypilka S.A. - concept and design of the study; Trypilka S.A. - collection of data; Yehudina Ye.D., Trypilka S.A. - analysis and interpretation of data; Yehudina Ye.D. - writing the article; Trypilka S.A. - editing the article.

\section{References}

1. Vaglio A, Maritati F. Idiopathic Retroperitoneal Fibrosis. J Am Soc Nephrol. 2016 Jul;27(7):1880-9. doi: 10.1681/ ASN.2015101110. CrossRef PubMed

2. Ormond JK. Bilateral ureteral obstruction due to envelopment and compression by an inflammatory retroperitoneal process. J Urol. 1948 Jun;59(6):1072-9. doi: 10.1016/s00225347(17)69482-5. CrossRef PubMed

3. Kamisawa T, Zen Y, Pillai S, Stone JH. IgG4-related disease. Lancet. 2015 Apr 11;385(9976):1460-71. doi: 10.1016/ S0140-6736(14)60720-0. CrossRef PubMed

4. van Bommel EFH, Jansen I, Hendriksz TR, Aarnoudse ALHJ. Idiopathic retroperitoneal fibrosis: prospective evaluation of incidence and clinicoradiologic presentation. Medicine (Baltimore). 2009 Jul;88(4):193-201. doi: 10.1097/ MD.0b013e3181afc420. CrossRef PubMed

5. Goldoni M, Bonini S, Urban ML, et al. Asbestos and smoking as risk factors for idiopathic retroperitoneal fibrosis: a case-control study. Ann Intern Med. 2014 Aug 5;161(3):181-8. doi: 10.7326/M13-2648. CrossRef PubMed

6. Della-Torre E, Rigamonti E, Perugino C, et al. B lymphocytes directly contribute to tissue fibrosis in patients with IgG4related disease. J Allergy Clin Immunol. 2020 Mar;145(3):968981.e14. doi: 10.1016/j.jaci.2019.07.004. CrossRef PubMed 
7. Mattoo H, Mahajan VS, Maehara T, et al. Clonal expansion of CD4(+) cytotoxic T lymphocytes in patients with IgG4related disease. J Allergy Clin Immunol. 2016 Sep;138(3):825838. doi: 10.1016/j.jaci.2015.12.1330. CrossRef PubMed

8. Umehara H, Okazaki K, Masaki Y, et al. Comprehensive diagnostic criteria for IgG4-related disease (IgG4-RD), 2011. Mod Rheumatol. 2012;22(1):21-30. doi: 10.1007/s10165-0110571-z. CrossRef PubMed

9. Wallace ZS, Naden RP, Chari S, et al. The 2019 American College of Rheumatology/ European League Against Rheumatism Classification Criteria for IgG4- Related Disease. Arthritis Rheumatol 2020;72(1):7-19. doi: 10.1002/art.41120. CrossRef PubMed

10. Khosroshahi A, Wallace ZS, Crowe JL, et al. International consensus guidance statement on the management and treatment of IgG4-related disease. Arthritis Rheumatol. 2015 Jul;67(7):1688-99. doi: 10.1002/art.39132. CrossRef PubMed
11. Yunyun F, Yu P, Panpan Z, et al. Efficacy and safety of low dose Mycophenolate mofetil treatment for immunoglobulin G4-related disease: a randomized clinical trial. Rheumatology (Oxford). 2019 Jan 1;58(1):52-60. doi: 10.1093/rheumatology/ key227. CrossRef PubMed

12. Wallace ZS. Kawano M, Saeki T, Nakashima H. IgG4-related kidney disease and retroperitoneal fibrosis: an update. Mod Rheumatol. 2019 Mar;29(2):231-239. doi: 10.1080/14397595.2018.1554321. CrossRef PubMed

13. Surcel C, Mirvald C, Pavelescu C, et al. Management of idiopathic retroperitoneal fibrosis from the urologist's perspective Ther Adv Urol. 2015 Apr;7(2):85-99. doi: 10.1177/1756287214565637. CrossRef PubMed

Received 25.01.2021

Revised 15.02.2021

Accepted 02.03.2021

Information about authors

Ye.D. Yehudina, MD, PhD, professor, Head of the Educational Center, Clinic of Modern Rheumatology, Kyiv, Ukraine; https://orcid.org/0000-0001-8702-5638

S.A. Trypilka, MD, PhD in medicine, Associate of Professor, Rheumatologist of Communal Non-Commercial Enterprise of Kharkiv Regional Council "Regional Clinical Hospital", Kharkiv, Ukraine; https://orcid.org/0000-0001-6630-9893

Трипілка С.А.', Єгудіна .Д. $^{2}$

'Комунальне некомерційне підприємство Харківської обласної ради «Обласна клінічна лікарня», м. Харків, Україна ${ }^{2}$ Клініка сучасної ревматології, м. Київ, Україна

\section{Клінічний випадок розвитку ретроперитонеального фіброзу (хвороби Ормонда) у практиці ревматолога}

Резюме. Заочеревинний (ретроперитонеальний) фіброз (РПФ) - рідкісне захворювання, що характеризується розростанням запальної та фіброзної тканини в заочеревинному просторі. Зазвичай ці розростання локалізуються навколо інфраренальної частини черевної аорти та клубових артерій, часто покриваючи сечоводи або інші органи черевної порожнини. Ідіопатичні захворювання становлять $70 \%$ випадків. РПФ може бути асоційований з імуноглобуліном G4 (IgG4), що є причиною двох третин випадків ідіопатичного РПФ. Вторинний РПФ може розвинутись унаслідок інфекцій, злоякісних новоутворень, прийому лікарських препаратів, заочеревинної кровотечі або інших захворювань. Описано клінічний випадок ідіопатичного РПФ, імовірно, асоційованого з IgG4, у пацієнта, який пройшов симптоматичне опе- ративне лікування в урологічній клініці та продовжив лікування в ревматолога патогенетичною терапією (метилпреднізолон і мофетилу мікофенолат) зі значним поліпшенням. Для ревматологів дана патологія, безумовно, має клінічний інтерес, оскільки в основі цих змін лежать процеси, аналогічні таким при системних захворюваннях сполучної тканини, i з огляду на низьку захворюваність, що становить від 0,1 до 1,3 випадку на 100000 людей на рік. Однак частіше такі пацієнти відразу потрапляють на прийом до лікарів суміжних спеціальностей (урологів, нефрологів, хірургів, судинних хірургів), що підкреслює важливість розгляду цього клінічного випадку. Ключові слова: ретроперитонеальний фіброз; IgG4-асоційоване захворювання; клінічний випадок; діагностика; лікування

\section{Триполка С.А.', Егудина Е.Д. ${ }^{2}$}

'Коммунальное некоммерческое предприятие Харьковского областного совета «Областная клиническая больница", 2. Харьков, Украина

${ }^{2}$ Клиника современной ревматологии, г. Киев, Украина

\section{Клинический случай развития ретроперитонеального фиброза (болезни Ормонда) в практике ревматолога}

Резюме. Забрюшинный (ретроперитонеальный) фиброз (РПФ) - редкое заболевание, характеризующееся разрастанием воспалительной и фиброзной ткани в забрюшинном пространстве. Обычно эти разрастания локализуются вокруг инфраренальной части брюшной аорты и подвздош- ных артерий, часто покрывая мочеточники или другие органы брюшной полости. Идиопатические заболевания составляют 70 \% случаев. РПФ может быть ассоциирован с иммуноглобулином G4 (IgG4), что является причиной двух третей случаев идиопатического РПФ. Вторичный РПФ может 
развиться вследствие инфекций, злокачественных новообразований, приема лекарственных препаратов, забрюшинного кровотечения или других заболеваний. Описан клинический случай идиопатического РПФ, вероятно, ассоциированного с IgG4, у пациента, прошедшего симптоматическое оперативное лечение в урологической клинике и продолжившего лечение у ревматолога патогенетической терапией (метилпреднизолон и мофетила микофенолат) со значительным улучшением. Для ревматологов данная патология представляет безусловный клинический интерес, поскольку, с одной стороны, в основе данных изменений ле- жат процессы, аналогичные таковым при системных заболеваниях соединительной ткани, а с другой стороны - это редкая патология, встречаемость РПФ составляет от 0,1 до 1,3 случая на 100000 человек в год. Однако чаще такие пациенты сразу попадают на прием к врачам смежных специальностей (урологам, нефрологам, хирургам, сосудистым хирургам), что подчеркивает важность разбора такого клинического случая.

Ключевые слова: ретроперитонеальный фиброз; IgG4-acсоциированное заболевание; клинический случай; диагностика; лечение 